\title{
A Critical Discourse Analysis Approach to News Discourses and Social Practices on Race in Brazil
}

(Uma Abordagem de Análise Crítica de Discursos e Práticas Sociais Sobre a Questão Racial no Brasil)

Célia Maria Magalhães

(UFMG)

ABSTRACT: In this paper I set out from Brazilian social theories on race to analyse a contemporary corpus of news reports in a Brazilian broadsheet newspaper. The aim is investigating change in mediated discourses on race. Based on Critical Discourse Analysis $(C D A)$ and with the help of corpus linguistics methodological tools I focus on lexical items used to categorise race, the semantic relations created and their association with discourse representation in the newspaper. The combined analysis of semantic relations and interdiscursivity has allowed for the perception of tensions over the use of terms from different semantic fields to categorize race and of conflicting discourses of race classification in the paper. The analysis has also allowed for a cautious interpretation of dialogicality and of different orientations to racial difference, following the social research inventories in Fairclough (2003) in the reports.

KEY-WORDS: race classification; semantic relations; interdiscursivity; dialogicality; race discourses.

RESUMO: Neste trabalho parto de teorias sociais sobre a questão racial para analisar um corpus de reportagens contemporâneas de um jornal brasileiro de grande circulação. O objetivo é investigar a mudança nos discursos mediados sobre a questão racial. Com base na teoria da Análise Crítica do Discurso ( $A C D$ ) e com o suporte de ferramentas metodológicas da lingüistica de corpus, focalizo os itens lexicais usados para categorizar raça e as relações semânticas que estes constroem associados com a representação de discurso no jornal. A análise combinada das relações semânticas e da interdiscursividade permitiu perceber que há uma tensão no uso de termos de campos semânticos diferentes para categorizar a questão racial e discursos conflitantes sobre a classificação de raça no 
jornal. A análise também permitiu uma interpretação cautelosa da dialogicidade e das diversas orientações para a diferença racial, utilizando os inventários de pesquisa social de Fairclough (2003).

UNITERMOS: classificação de raça; relações semânticas; interdiscursividade; dialogicidade; discursos sobre raça.

\section{Introduction}

Brazil is often represented, inside the country and abroad, as a place where the encounter of the three races, the indigenous, the Africans and the Portuguese in the aftermath of colonization produced a smooth mixing of races and, thus as a country where there is no racial prejudice and discrimination. This representation stands for the strong ideology of racial democracy in the country which is unique as compared to European, North American and even the rest of South American race ideologies. However, since the seventies several academic studies as well as political action of the Black movements in Brazil have been trying to contest this dominant discourse. In 1995, partly due to debates on race discrimination promoted by the United Nations Brazil celebrated the tercentenary of Zumbi's death and named the date of November 16 "day of black consciousness". More recently Brazil participated in the 2001 World Conference against Racism, Racial Discrimination, Xenophobia and Intolerance in Dunbar. Both years, 1995 and 2001, allowed for a stronger debate on race in Brazilian media and, especially the year of 2001 has brought to the fore discursive changes on the issue in the country (Magalhães, 2004; Caetano e Magalhães, forthcoming). Some of the aspects of this change can be associated with recently approved legislation on education, with the inclusion of African history and culture in the national curriculum and the establishing of quotas for Blacks at universities ${ }^{1}$. One key aspect of this change is, however, a struggle over the different discourses on race which is best represented in the mediated discourse of newspapers.

In this paper I set out from Brazilian social theories on race to analyse a corpus of news reports of a Brazilian broadsheet newspaper. I argue that

\footnotetext{
1 These changes seem to be associated with monitoring by the UN, after the Conference at Dunbar, of action being taken in the country to mitigate social exclusion and discrimination.
} 
there may be semantic relations created around different race categorisations which associated with discourse representation in the reports are revealing of conflicting discourses of race classification. In order to achieve this aim I focus categorizations of skin colour such as negra(s), negro(s), pretos, (Black $\left.(\mathrm{s})^{2}\right)$, and pardos (Browns). I try to answer the following questions: What semantic relations are created around these terms? To what extent can these relations be mapped onto discourse representation in the newspaper? To what extent can the articulation of semantic relations and interdiscursivity point at the newspaper's orientations to the issue? In answering these questions, I suggest that there are different discourses on race and a simultaneous reproduction and challenging of the discourse of racial democracy in the broadsheet. I also suggest that an association between race and socioeconomic issues is constructed, which may indicate both an intertwining of the two aspects in Brazilian identity in view of the systematic economic oppression of Brazilian populations of African descent in the country and a concealment of racial prejudice under the disguise of socioeconomic prejudice.

\section{Theoretical background}

My aim in this section is to approach recent discursive and social practices on the racial issue in $\mathrm{Brazil}^{3}$ from a CDA perspective. The representation of Brazil as a racially democratic country stems from an ideal of not segregating Whites and Blacks after slavery as it happened in the USA (see Freyre, 1966 for an analysis of Brazil as a racially democratic country). Guimarães (2003) explains that the mythical representation of the Brazilian society as one without racial prejudice or discrimination originates from the idea, widespread in the USA and Europe, that Brazil did not have a clear-cut colour line and, for that matter, people of colour would be allowed the same opportunities as Whites regarding jobs, wealth and prestige.

\footnotetext{
2 Negro (masculine), negra (feminine), preto (masculine) and preta (feminine) are lexical choices in Brazilian-Portuguese for the colour or the skin colour black. Negro and negra were adopted by the Black movement to classify the group of Blacks and Browns as African descendants, and to avoid the presumably negative connotation of preto and preta. However, all the items can be used as insults in the context of an overt racist discourse. I have decided to use upper case for the first letter in the English translation of these words when they stand for racial groups.

3 The intention is not, however, to offer a broad review of Brazilian race theories.
} 
Schwarcz (2000) refers to the kind of racial relationship constructed in the country under the myth of non-segregation and non-discrimination as cordial racism, i.e. a modality of racial relationship in which prejudice would be forbidden and where it existed it should be hidden, especially under the disguise of another issue, that of the huge socioeconomic gap between Brazilian citizens. Schwarcz further suggests Brazil should be identified on the basis of race, claiming the issue cannot be thoroughly understood as long as it is limited to or hidden under class, i.e. socioeconomic differences.

Piza (2003) traces studies which are more revealing of racial discrimination and of social exclusion of Blacks from Brazil's projects of social and economic progress back to the seventies, when comparisons of educational levels, jobs and salaries of the different racial groups began to be made based on statistical data. Guimarães (2003) adds that it is also after the seventies that Black movements campaign more overtly against racism and inequalities to be recognized inside and outside the country. Following the publication of the first law banning racial discrimination in 1950, the 1988 Constitution determined that social practice was a crime and several other steps were advanced against it.

Other recent statements in the area suggest the strong ideology of racial democracy in Brazil has led to an apparent invisibility of the racial issue in the wider discourse. One of the strategies to achieve this invisibility was the categorisation of mixed race people through the use of a wide colour range of classification. Nascimento (2003) describes this representation as one which took on board criteria of purely aesthetic nature, with colour as a sign of celebration of the mixing of races, in which the notion of racial or ethnic origin would not play a part and thus would not stimulate racism and discrimination. Nascimento names this form of ideological discursive de-racialization colour sorcery. I would rather name it, following Fairclough (2003) and Chouliaraki and Fairclough (1999), aestheticization of racial identities in the country for this discourse shifts away more or less consciously from a race classification and turns to an aesthetic skin colour classification in order to create a particular image of these identities, a conflicting image which simultaneously aims at an whitening policy and at a celebration of harmony in the interracial encounters. 
Classification is used here in Bourdieu's sense, as interpreted in Fairclough (2003: 213) as pre-constructed and taken-for-granted ways of dividing up parts of the world (which) continuously generate particular 'visions' of the world, ways of seeing it, and acting upon it). On the issue of skin colour classification Carone (2003) asserts that people of African descent in Brazil use a detailed range of colours to identify themselves. The author observes, however, that this racial group does not seem to endorse the colour classification used by the national institution for census, Instituto Brasileiro de Geografia e Estatística (IBGE) since 1940 which is brancos, pretos, pardos, and amarelos, (Whites, Blacks, Browns, and Yellows) (see Piza and Rosemberg, 2003). The range of different lighter or darker shades of colour compiled in these recent studies suggests a desire, pointed out by Sodré (2000), to pass for mixed due to the strong naturalized discourse according to which the more one can get to a lighter shade of blackness the more one is approaching whiteness and, for that matter, humanity.

It should be noted here that the Black movement started using the lexical item negro instead of preto from the sixties on in order to include both negros and pardos in the same group of African descent; in a move towards a race classification which would allow the group thus formed and classified to be reported as a minority group (Piza and Rosemberg 2003). They were thus, I suggest, trying to reconstruct Black's identity by challenging the existing classification. However, perhaps out of habitu' (see Chouliaraki and Fairclough, 1999 and Lemke, 1995 on a reading of Bourdieu's concept babitus) they ended up in the longstanding aesthetical classification based on skin colour (after all, negro is just another lexical item in the language which as well as preto are hyponyms of the super ordinate term skin colour or colour. It is also perhaps due to habitus, or an embodied disposition to the colour classification, that negro is still most often devoid of this reconstructed meaning outside the Black movement and can be used as an insult almost as often as preto, as Guimarães (2003) shows. For Guimarães, the term negro is a verbal or chromatic synthesis of stigmas regarding racial identity and the colour itself acquires a stigmatising function as its negative senses in the dictionaries of the language suggest.

Carone and Nogueira (2003) find out that race is represented in Brazilian newspapers as an issue of an explosive nature, as a problem attributed to Blacks themselves, and most often as the object of conflicts not inside but outside Brazil, which reinforces the discourse of racial 
democracy. Sodré (2000) also devotes part of his work to an investigation of the racial representation in the press. He adds the terms claros (light) and escuros (dark) to the multifaceted Brazilian colour scheme and the notion that the lighter the skin the higher in a power hierarchy.

Thus a central and unique issue in Brazilian culture is the aestheticization of racial identity, which nevertheless seems to be contested by contemporary social theorists who regard it as the basis of a strong ideology of racial democracy and its extended construction, cordial racism. I will try to show through a close analysis of discourses in contemporary news reports that the discourse of race aestheticization which is constructed through a skin colour classification is simultaneously being deployed and challenged when it comes to the fore with other classificatory schemes especially after the paper starts drawing upon the discourse of the legislation previously mentioned and starts articulating it with the colour classificatory scheme. I thus argue that an analysis of the issue is better achieved through a combination of textual analysis and social research, as proposed by one of the schools of CDA whose forerunner is Norman Fairclough, the social theory of discourse.

For the suggestion of CDA as a powerful analytical tool of Brazilian racial issue as depicted above I would like the readers to refer to the basic principles of the theory in Reisilg and Wodak (2002). I will further argue for the choice of the CDA school associated with Chouliaraki and Fairclough (1999) and Fairclough $(1992,2001,2003)$ as a theoretical ground for studying the tension over terms to write or report race in the broadsheet analysed even though the school's concern has not been race or racism but globalisation and its effects on discourses. Therefore, I single out the different CDA schools which are mainly concerned with racial issues in order to justify my choice.

Van Dijk (1998, 2003, amongst others) is a multidisciplinary framework which privileges a socio-cognitive approach to racism. Wodak (Reisigl and Wodak, 2001; Wodak, 2002) is an approach grounded on a concept of social critique involving three main interconnected aspects, the first two associated with the dimension of cognition, and the last one related to the dimension of action. However, I will not adopt any of these frameworks here for at least two main theoretical reasons. Van Dijk and Wodak, provide powerful tools for the analysis of racist discourses from 
European perspectives. Their theories certainly have been a great contribution to research on racism in the media as well as in other institutions in Europe; however, it should be said they are Eurocentric and, for that matter, cannot account for a Brazilian perspective of the issue, unique as it is with its constructions of racial democracy and cordial racism. As I am interested in unthreading this naturalized discourses on race in conflict with other, new discourses in the newspaper I choose Chouliaraki and Fairclough (1999) and Fairclough (2001, 2003). This school first of all has a strong interdisciplinary relation with social theories and concepts which allows for an analysis of the complex intertwining of socioeconomic and racial differences in Brazil. It also facilitates a focus in interdiscursivity and has a strong relation with systemic functional linguistics (SFL) whose articulations with social and anthropological theories best suit my purpose of analysis as well as provide textual categories of analysis.

\section{Materials and Methods}

Folha de São Paulo, well-known in Brazil as Folha, has been taken as a paper which inherently reproduces as well as constructs a more liberal view on the issues it divulges. However, to the best of my knowledge it does not usually take readers' ethnic diversity into account for the choice of news it covers. In spite of this, it published a whole supplement on cordial racism and colour prejudice in 1995 (Folha de São Paulo/DataFolha, 1995); it has also been lately positioning itself as constructing anti-racist discourses (d'Adesky, 2001).

The corpus was collected from the online version of the newspaper from January to July 2003. The keywords raça, racismo and racista were used in the search for texts to compile the corpus. I take keywords here as described by Williams (1988: 15), i.e. in two connected senses: they are significant, binding words in certain activities and their interpretation; they are significant, indicative words in certain forms of thought. I chose not to use the notion of keywords which grounded Keywords of WordSmith Tools, i.e., words that are considered outstanding in their frequencies in a corpus as compared to another, larger reference corpus. I did not want to analyse words based on their outstandingness (Scott, 2000) in the corpus; I was interested in the fact that they would lead me to the different discourses on, or forms of 
thoughts about, the issue in the newspaper. I also wanted to investigate these texts with a view to researching the deployment and challenging, or contesting of the different di-visions on, or classifications of, race. The corpus thus compiled contains 73 texts $(25,417$ tokens) published in different sections of the newspaper. Table I depicts these different sections, the number of texts in each section, classified according to the genres they belong to, and the origin of the news, categorised as local, national or international:

Table I: News Reports in Folha online - January to July 2003

\begin{tabular}{|l|l|l|}
\hline Sections & $\begin{array}{l}\text { (Number of texts } \\
\text { and) Genres }\end{array}$ & Origin of news \\
\hline Cotidiano (local) & 22 reports & Local \\
\hline $\begin{array}{l}\text { Folhinha (Children's } \\
\text { special) }\end{array}$ & 12 reports & Local \\
\hline $\begin{array}{l}\text { Mundo (World } \\
\text { news) }\end{array}$ & $\begin{array}{l}10 \text { reports } \\
2 \text { interviews }\end{array}$ & $\begin{array}{l}\text { USA (8), England (1), Brazil (1) } \\
\text { Brazil (1), International (1) }\end{array}$ \\
\hline $\begin{array}{l}\text { Brazil (political } \\
\text { news + editorials) }\end{array}$ & $\begin{array}{l}10 \text { reports } \\
2 \text { editorials }\end{array}$ & $\begin{array}{l}\text { Brazil } \\
\text { Brazil (1), Brazil and USA (1) }\end{array}$ \\
\hline Sports & 8 reports & International \\
\hline TV & $\begin{array}{l}1 \text { report, } 1 \\
\text { interview }\end{array}$ & Local \\
\hline Science & 1 report & Brazil \\
\hline Ilustrada (features) & $\begin{array}{l}1 \text { review } \\
1 \text { report }\end{array}$ & $\begin{array}{l}\text { Brazil } \\
\text { USA }\end{array}$ \\
\hline $\begin{array}{l}\text { Mais (academic/ } \\
\text { cultural issues } \\
\text { Sunday section) }\end{array}$ & 1 essay & Brazil \\
\hline Tourism & 1 report & South Africa \\
\hline
\end{tabular}

For methodological purposes I took as news reports texts in which the features were more prominently those associated to news reports such as the stress on a recent public event in accordance with news values (see van Dijk, 1986; Bell, 1991; Fowler, 1991; Fairclough, 1995; Scollon 1998, among others, for analyses of news reports and media discourse). Table I shows that Folha published a total of 47 news reports in which there was a 
focus on race in Brazil: 22 local reports; 10 national reports; 12 in the children's section; 1 in the world section; 1 in the section on TV, and 1 in the section on science. It thus shows that race is being reported as an issue that takes place within the country itself rather than in foreign countries as it used to be reported according to research referred to in the first section of this paper.

As methodological steps I first focused on colour terms in order to investigate their semantic relations in the whole corpus. With the help of corpus linguistics I have explored semantic relations as an important aspect of the construction of race in the corpus (see related studies such as Krishnamurthy, 1996, and Stubbs, 1996). The corpus linguistics tool used was the concordance line (cf. Hard-Mautner, 1995) as produced with the Concord function in WordSmith Tools. Secondly I focused on interdiscursivity (see Fairclough, 1992, 2003; see also Lemke, 1995) in the local or national reports in order to investigate how different discourses are articulated together. Concordance lines were also useful as a first step to scrutinise indirect and direct discourse. As search words I established the words que (that, always textualised in Brazilian Portuguese after reporting verbs), para (for), segundo and acordo (both meaning according to, the latter taking part in the cluster de acordo com), some of the more frequent forms used in indirect discourse. I have also established the inverted commas followed by an asterisk (*) as a search form for direct discourse or $\mathrm{DD}(\mathrm{S})$. However, these also demanded substantially expanding the lines and close scrutinising of the larger context. Finally I analysed dialogicality and difference based on the data obtained with reference to semantic relations and interdiscursivity in the broadsheet.

\section{Data analysis and discussion 1: semantic relations}

I have analysed the occurrences of each skin colour category in order to find whether they were primed for any collocational use in the corpus. Priming is defined by Hoey (in press) as the fact that as the word is learnt through encounters with it in speech and writing, it is loaded with the cumulative effects of those encounters such that it is part of our knowledge of the word that it cooccurs with other words.

I have also compared these primings in the corpus with the ones presented in two dictionaries of the Brazilian Portuguese language (Holanda 
Ferreira, 2004, authoritative dictionary based on lexicographical studies, and Borba, 2002, contemporary corpus-based dictionary) and in Banco de Português (BP) (Bank of Brazilian Portuguese), a corpus with 240 million words in 2003. At present access to BP is only possible through a sample of about one million words available online, so it should be borne in mind that analyses based on it are restricted by this fact. Table II, III and IV, below show the number and percentage of occurrences of lexical items stemming from the lemmas etn-, rac- and negr- in the corpus of 25.417 tokens:

Table II: Frequency of ethnics categories

\begin{tabular}{|l|l|l|}
\hline \multirow{2}{*}{ Lexical items } & \multicolumn{2}{|l|}{ Occurrences } \\
\cline { 2 - 3 } & Number & $\mathbf{( \% )}$ \\
\hline Etnia(s) & 6 & 0.02 \\
\hline Étnico(a)(s) & 11 & 0.04 \\
\hline Total & 17 & 0.06 \\
\hline
\end{tabular}

Table III: Frequency of race categories

\begin{tabular}{|l|l|l|}
\hline \multirow{2}{*}{ Lexical items } & \multicolumn{2}{|l|}{ Occurrences } \\
\cline { 2 - 3 } & Number & $\mathbf{( \% )}$ \\
\hline Raça & 10 & 0.04 \\
\hline Racial & 29 & 0.11 \\
\hline Total & 39 & 0.15 \\
\hline
\end{tabular}

Table IV: Frequency of skin colour categories

\begin{tabular}{|l|l|l|}
\hline \multirow{2}{*}{ Lexical items } & \multicolumn{2}{|l|}{ Occurrences } \\
\cline { 2 - 3 } & Number & $(\mathbf{\%})$ \\
\hline Negra & 36 & 0.14 \\
\hline Negras & 21 & 0.08 \\
\hline Negro & 38 & 0.15 \\
\hline Negros & 107 & 0.42 \\
\hline Negritude & 1 & 0.00 \\
\hline Negreiro & 1 & 0.00 \\
\hline Total & 204 & 0.80 \\
\hline
\end{tabular}


Lexical items stemming from negr-, i.e., skin colour categories, occur almost four times more than items stemming from the lemmas etn- or rac, race/ethnics categories. Table $\mathrm{V}$ shows the priming of the lexical items which are skin colour categories.

Table V: Priming of skin colour categories

\begin{tabular}{|l|l|l|l|l|}
\hline \multirow{2}{*}{ Items } & \multicolumn{3}{|l|}{ Epithet } & Noun \\
\cline { 2 - 5 } & Number & $(\boldsymbol{\%})$ & Number & $(\boldsymbol{\%})$ \\
\hline Negra & 32 & 88.89 & 4 & 11.11 \\
\hline Negras & 14 & 82.35 & 3 & 17.65 \\
\hline Não-negras & 2 & 50.00 & 2 & 50.00 \\
\hline Negro & 27 & 71.05 & 11 & 28.95 \\
\hline Negros & 26 & 24.30 & 81 & 75.70 \\
\hline
\end{tabular}

The priming of negra(s) (singular and plural feminine forms) seems to be their occurrence as epithets (noun modifiers or attribute). The fewer occurrences of these words as nouns may support the notion developed by Guimarães (2003) about their use as a racial insult or, I argue, to the fact that they embody a subtle reference to slavery, which could be read out of definitions in Holanda Ferreira (2004), in Borba (2002), and of occurrences in the BP.

One unusual feature is the occurrence of negra (colour category) as an attribute of the abstract noun pobreza (poverty) once in the corpus, as well as its occurrences as a noun modifier as in pobreza negra (black poverty), beleza negra (black beauty), cidade negra (black city), and história negra (black history). In the nominal group pobreza negra a representation of possessivatization (van Leeuwen, 1996), i.e., pobreza dos negros (Blacks' poverty) is relayed as an epithet of an abstract entity, creating an ambiguity which contributes to the conflicting discourses in the newspaper. This transformation could also be interpreted in the light of what Hoey (1991) names coberence process of lexical transference: ... (it) occurs when we transfer (against logic) an attribute from one nominal to a related nominal, even though in the example it seems the transference is not exactly of a single attribute to related nominals but of a possessive into an attribute - a skin colour category - which is likely to give value to the abstract entity poverty inasmuch as it 
is itself a transformation of an attribute (poor) that is associated with Brazilian people of African descent. Moreover, the epithet itself and the associated lexical items in the sentences may be said to create a negative semantic prosody (see Sinclair, 1991; Stubbs, 1996; Partington, 1998 and Sardinha, 2004 for the concept) as is the case with violence in example 1) and erase in example 2$)^{4}$, below:

1) ...São Paulo é a maior cidade negra do país. Não dá para combater a violência sem desenvolver programas para esse grupo. (...São Paulo is the largest black city in the country. You cannot combat violence without developing programs for this group.) (Folha, 30/06/03)

2) No Brasil, documentos que registravam as origens desses povos foram queimados logo após a abolição da escravatura (1888). A idéia era apagar a história negra do país. (In Brazil, documents which recorded these peoples' origins were burnt soon after slavery abolition (1888). The idea was to erase the black history of the country.) (Folha, 01/02/03)

Therefore a stronger association between class and race seem to be created in pobreza negra due to the transformation above mentioned, bringing to the fore an inherent association between the two lexical items, an issue I shall get back to later in this paper, where I will give further examples.

The lexical item não-negras is an interesting addition of the corpus to the vocabulary of the language as, I argue, a less monolithic alternative for brancas in which other racial groups could be included. It also indicates a change in Brazilian naturalized skin colour classification; however, the basis for classification is still skin colour as example 3), below shows:

3) Os grupos foram divididos em 542 negras e 526 não-negras. (The groups have been divided in 542 blacks [females] and 526 non-blacks [females].) (Folba, 13/07/03)

The priming of negro suggests it also occurs mainly as epithets, noun modifiers or attribute. However, negros occurs more frequently as nouns. Furthermore, negros occurs more often in prepositional phrases where the heads are proportions, which suggests the kind of quantitative research the newspaper seems to privilege as well as an objectification of people of African descent (van Leeuwen, 1996).

\footnotetext{
4 I have underlined words or collocations under analysis in all the examples.
} 
Finally, I have also investigated the words pretos and pardos. The few instances of these lexical items in BP and their dictionary definitions suggest their priming is their occurrence as epithets with a negative meaning. The rare occurrences of pretos (2 occurrences of pretos and 1 occurrence of preta) in the corpus suggest, moreover, that these items are being replaced by negros/negra, presumably because these terms had spread in the wider discourse after the Black movement's new classification of the racial group. The findings for pardos (8 occurrences) also reveal a stronger tendency for suppression for the same reason. These items seem to be more frequent in the collocations pretos e pardos, brancos e pardos, associated with the classification used by IBGE, but pardos also collocates with negros in negros e pardos, which is conflicting, inasmuch as the former was supposed to include the latter in the discourse of the Black movement. The next section is an attempt at an interpretation of these findings in the light of what Fairclough (2003) defines as interdiscursivity in genres.

\section{Data analysis and discussion 2: discourse representation and interdiscursivity}

Fairclough (2003) draws on Vološinov (1978) and Bakhtin (1986) to argue for intertextuality as a property responsible for the opening up of difference in texts. His is a very broad view of intertextuality for he considers other less obvious ways of embedding elements in texts such as the various forms of indirect reporting or the various ways of attributing or not attributing what is said, written or summarized to people who said or wrote something (see the concepts of manifest and constitutive intertextuality in Fairclough, 1992).

There are several detailed studies on manifest and constitutive intertextuality, or the way different discourses are represented in written texts (Leech and Short, 1981; Fairclough, 1995; Thompson, 1996; Scollon, 1998, amongst others). My purpose is an analysis of interdiscursivity through the choice of lexical items to report race and not a thorough account of discourse representation in the newspaper. Thus I have taken on board the categories of discourse representation from Fairclough (1995), the ones defined according to the mode of discourse, i.e., direct discourse (DD), indirect discourse (ID), (DD(S), cases of slipping between the modes, and UNSIG(nalled), cases where ... what is clearly secondary discourse appears in 
primary discourse without being explicitly marked as represented discourse... (1995: 55) and which include what is taken in standard accounts of the English grammar as free indirect discourse. I also base on Short, Semino and Culpepper (1996) which suggest most British broadsheet discourse representation falls into ID seemingly because of their main way of summarising what people say and of the balanced image they cherish, even though DD is also crucial in their reporting of news and $\mathrm{DD}(\mathrm{S})$ is becoming more and more frequent.

The occurrences of ID representation are about twice the number of the occurrences of $\mathrm{DD}$ or $\mathrm{DD}(\mathrm{S})$. These data confirm a feature of news reports, i.e., they privilege indirect report in their mediated discourse (see Bell, 1991; Short, Semino and Culpepper, 1996; Scollon ,1998, amongst others). In terms of interdiscursivity what the data interestingly show is that in mediating the different discourses the reports reproduce and/or help create the conflicting discourses on race through the different classifications, skin colour and race/ethnics.

Reports from Folbinha recontextualise the law determining that African history and culture be taught in elementary and secondary schools (for the notions of recontextualisation and genre chains, see Fairclough 2003). A report entitled Diversidade na escola (Diversity at school) informs in the lead that a law has been approved which determines that all schools should from that time on teach cultura e história afro-brasileiras (Afro-Brazilian culture and history). In the first paragraph of the report, however, a hypothetical question (see Myers, 1999) introduces the colour term Blacks, as in example 4):

4) Alguns de vocês devem se perguntar: "Mas já não aprendi sobre os negros na escola?" (Some of you might be wondering: "But haven't I already learnt about Blacks at school?") (Folha, 01/02/03)

Later in the same news, when reporting what some schools and teachers in São Paulo had already been doing on the subject words such as tradição afro-brasileira (Afro-Brazilian tradition) and cultura africana (African culture) are used, the second presumably used by the teacher whose voice is indirectly reported. The teacher is also reported as talking about a guerreiro negro (Black warrior) and the lack of heróis negros (Black heroes) in stories, which suggests there is tension over the terms used as well as conflicting discourses on race. 
In another report from the children's section, entitled Falam os professores (Teachers speak) there is DD of three different teachers. I reproduce one of them below, as example 5) to show the conflicting discourses on race/skin colour through lexical choice and semantic relations:

5) "Meu objetivo é quebrar a noção de que a bistória africana começa com os europeus e com os negros escravizados." (My aim is to erase the notion that African history begins with the Europeans and the enslaved Blacks). (Folha, 01/02/03)

African bistory in 5) may stem from the discourse of the law, the enslaved Blacks (and not the enslaved Africans, as expected), used right after the Europeans, however, suggests that in the wider discourse in Brazil, and elsewhere, African people are classified on the basis of their skin colour and not of their geopolitical descent as are other people, e.g. the Europeans. In a dialectics of appropriation/colonization of discourses (Chouliaraki and Fairclough, 1999), the discourse of skin colour classification - a discourse colonised by the field of aesthetics - is simultaneously being deployed and challenged by a discourse of geopolitical classification which, in turn, seems to be appropriated from the legislation.

The last report in Folbinha, entitled Brasil com jeito de África (Brazil, African style), is attributed to an anthropologist who published a book on African cultures for children. There is a network of lexical choices such as African peoples, tradition from Africa, the number of Africans, and others which construct semantic relations, bringing in to the report a struggle between different discourses on the issue. The only lexical choice related to skin colour comes at the end of the text when documents which tell us the story of African peoples in Brazil are referred to by the anthropologist. Example 2), from the previous section, is reproduced below as 6).

6) No Brasil, documentos que registravam as origens desses povos foram queimados logo após a abolição da escravatura (1888). A idéia era apagar a bistória negra do país. (In Brazil, documents which recorded these peoples' origins were burnt soon after slavery abolition (1888). The idea was to erase the black history of the country.) (Folha, 01/02/03)

Another piece of news associated with the law reports on the fact that a young student had to be transferred from school twice because the schools she studied at were not prepared to deal with her peers' racial insults. 
Examples 7) and 8), below show the representation of the girl's discourse in DS:

7) "Falavam que eu tinha cabelo duro, de Bombril. Eu reclamava com os professores, mas eles não faziam nada. Uma professora me disse que eu não tinha que ligar para as brincadeiras porque eu era uma menina linda e que isso to preconceitor ia acontecer durante toda a minha vida. Mas eu queria é que ela mandasse eles pararem", conta Ana Luiza. ("They used to say I had kinky hair. I used to complain to the teachers but they didn't do anything. A teacher told me not to mind the jokes for I was a beautiful girl and that [prejudice] was going to happen throughout my life. But what I would like her to have done was to have made them stop", Ana Luiza says.). (Folha, 18/05/03)

8) Ana Luiza dá uma receita contra o preconceito: "Quando fazem isso comigo eu vou lá e falo que racismo é crime e que eu vou processar e reclamar com a diretora". (Ana Luiza gives a recipe against prejudice: "When they do that to me I go there and say racism is a crime and that I'm going to sue them and complain to the director".). (Folha, 18/05/03)

Notice in 7) the conflict between what the student herself is reporting (which brings in another layer of discourse), i.e. what she seems to take as a racial insult presumably by her peers against her teacher's interpretation of it as jokes and the added bracket [prejudice] - whose addition it is, we may wonder - probably meant to interpret the cohesive device that the meaning of which could be easily traced back to jokes. Notice in 8) the newspaper introduces the student's discourse on how she tackled the situation with a Brazilian collocation dá uma receita (gives a recipe). This is likely to be another example of the difficulty of attributing voice in newspaper. On the one hand, the collocation could have been used by the girl herself. On the other, it could be interpreted as assessment or positioning (Buttny, 1997; Buttny and Williams, 2000) of the newspaper which, I argue, underestimates the issue when framing the student's attitudes to racism as instructions in a recipe.

What Buttny (1997) and Buttny and Williams (2000) suggest in their analysis of reported speech in focus groups discussing race can also be traced in another report, this time with a more positive assessment or positioning, though difficult again to attribute. The news is entitled Policiais militares são acusados de racismo contra garoto de 12 anos - PM teria ofendido menino negro em supermercado (Police officers are accused of racism against a 12 year old boy - Police officers allegedly offended Black boy in a 
supermarket). A young boy, whose initial is $\mathrm{K}$., is reported as accusing the police of racism not only because he was unjustly considered a suspect of stealing his own mother's car and thereby treated disrespectfully, but also because the police officer called him King Kong (a reference to his name's initial) as example 9), below shows. Notice that the attribution of the framing ironically (in the DD(S) ... mo motorista perguntou "quem era King Kong", ironicamente.), and thus of assessment of and positioning against the driver's speech, either to the newspaper, or the boy himself is anything but an easy endeavour. The tension created is simultaneously due to the difficulty of attributing voices and to the challenging of a discourse grounded on a classification which impersonalizes (van Leeuwen, 1996) or animalises (Guimarães, 2003) the boy:

9) Em seguida, o policial teria anotado o nome do menino e levado ao PM motorista da Blazer. Ao ver o nome do menino, o motorista perguntou "quem era King Kong", ironicamente. O menino registrou que se sentiu ofendido. (Next the officer would have written the boy's name and taken it to the other officer who was driving the police car. When he saw the boy's name, the driver asked ironically "who was King Kong”. The boy registered this as an offence.). (Folha, 10/02/03)

The following report stems from the approval of quotas for Blacks at universities in Brazil. The news is on the trial of Michigan University due to its quota system. An American lecturer who participated in a debate on affirmative action in Rio is the main newsmaker and some of her statements are reproduced in examples 10) to 12), below:

10) Lee explicou que, na Universidade de Michigan, alunos negros, hispânicos (...). (Lee explained that at Michigan University, Black, Hispanic students...). (Folha, 05/ 05/03)

11) Segundo Lee, a diversidade étnica nos campi das mais concorridas universidades norteamericanas é uma política voluntária. "Não somos obrigados a estipular esses critérios. Acho que as universidades procuram a diversidade (...)". (According to Lee, ethnic diversity on the campuses of the most famous North-American universities is a voluntary policy. "We don't have to estipulate these criteria. I think the universities seek diversity...). (Folha, 05/05/03)

12) Ela afirma, no entanto, que nenhuma universidade concorrida aceita abrir mão totalmente do critério acadêmico na admissão de estudantes de minorias. "É por isso que estudantes de minorias com bom desempenho nos testes (...)." (She states, however, that no famous university gives up academic criteria when accepting students from minorities. "That is why students from minorities with good performance in tests..."). (Folha, 05/05/03) 
Lexical items such as Black, stemming from skin colour classification, and Hispanic, stemming from a different classification (one of colonization, one may argue) may be thought as taken as hyponyms of the superordinate term race in the wider discourse in example 10). Diversity in example 11) and minorities in 12) stem from a discourse on race grounded on a classification based on (multi)culture, though, I argue, in a paradoxical way for not only should the semantic field of diversity imply the inclusion of different cultural groups but also a more unstable view of power where the lexical item minority would not have a part. Again, it is difficult to decide whether these tensions are in the mediated discourse of the newspaper or in the lecturer's discourse itself.

In another report on the issue of quotas at universities in Rio de Janeiro changes in the law are didactically explained in two sections, the current law, and the future modified law, through bullet items, some of them reproduced in examples 13) and 14), below:

13) $40 \%$ das vagas são reservadas apenas para candidatos que se declarem negros ou pardos ( $40 \%$ of the quotas are reserved only for candidates who declare themselves as Black or Brown). (Folha, 08/08/03)

14) (...) Com isso, um candidato que se declare negro, mas não venha de família carente, não terá direito à cota racial (Thus, a candidate who declares himself as Black but whose family is not poor will not be eligible to apply for a racial quota). (Folha, 08/08/03)

Notice in the examples the lexical items negro, negros and pardos where IBGE's discourse of skin colour classification, mentioned earlier in this paper, is represented, in the arena with other more recent discourses from academic texts or foreign discussions on the issue through the collocation cota racial.

The same conflict occurs in other reports not stemming directly from the law on quotas but coming out in the aftermath of this debate. In the first the news is a research on the social condition of people of African descent (afro-descendentes), a term used with scare quotes so that it is attributed to the researcher, whose voice is heard throughout the report. Example 15) below reproduces the sentence where the term is used: 
15) O economista contabilizou como negros, ou "afrodescendentes", a soma dos grupos que o IBGE classifica como pretos e pardos. (The economist counted as Blacks, or "Afro descendants" the sum of groups which IBGE classifies as Blacks and Browns.). (Folha, 06/06/03)

The researcher could be said to be contesting IBGE's skin colour classification for not only did he include Browns in the group of Blacks but he also named a new and differently constituted group, based on a race/ ethnics criterion. The association class/race can also be made in this report, in example 16), below:

16) "A gente sabe que, no Brasil, a pobreza tem cor: é negra. Os negros estudam menos, ganham menos e são mais pobres", afirma o economista da UFRJ, que é negro também. (You know that in Brazil poverty has a colour: it is black. Blacks study less, earn less and are poorer", states the economist from UFRJ who is Black himself). (Folha, 06/06/03)

The use of black (or, Black as it could also be translated due to the ambiguity created - it can stand for skin colour or racial group) as an attribute in a relational process where the carrier is it (referential, notdeployed cohesive device in the Brazilian Portuguese clause (ela) é negra, ela standing for poverty) (see Barbara and Gouveia, 2001) is later in the report re-echoed in another sentence likely to be retrieved from the research, this time as a modifier in a nominal group which may be replacing another, more common priming in the language, as I argued in the previous section. Notice in example 17) (which could be interpreted as UNSIG, with terms such as metropolitan used throughout the report seemingly appropriated from the study), below the collocation black poverty:

17) Na região metropolitana de São Paulo, por exemplo, $45 \%$ dos pobres são negros, mas, na população em geral, a proporção de negros cai para 32,1\%. No Rio acontece o mesmo: entre os pobres, 60,4\% são negros, uma proporção maior de negros que a verificada na população total, 53,5\%. A pobreza negra metropolitana acaba se refletindo em outras questões urbanas, como a violência - da qual os negros, principalmente os jovens do sexo masculino, são as principais vítimas. (In metropolitan São Paulo, for instance, $45 \%$ of the poor is Black but in the overall population of the state the proportion of Blacks falls to $32,1 \%$. It is the same in Rio: amongst the poor, $60,4 \%$ is Black, a higher proportion of Blacks in the city than in the overall population of the state, $53 \%$. Metropolitan black poverty is reflected upon other urban issues such as violence - of which Blacks, especially young males are the main victims) (Folha, 06/06/03) 
This new priming for the word black may be interpreted simultaneously as negative because of the semantic prosody created with terms such as violence and victims and as revealing of an intertwining of class and race as I argued before. This is reinforced in another example of DD in a report on affirmative action funded by Centro de Articulação de Populações Marginalizadas (Ceap) (Centre for Marginalized Populations), as shown in examples 18) and 19), below, the latter seemingly expanding on the meaning of Black as living in the slums, being less educated, in other words, being poor:

18) "A pobreza negra é uma realidade. (...)," afirma Ivanir dos Santos, coordenador do Ceap. (Black poverty is a reality...," claims Ivanir dos Santos, Ceap's coordinator.) (Folha, 30/06/03)

19) "Muitas vezes a gente não consegue subir no emprego lá fora só porque é negro. A gente é do morro, a gente tem menos estudo, aí tudo fica mais difícil. Pobreza é isso", afirma Elisete da Silva Napoleão, 39, uma das costureiras do grupo. ("Most of the time you don't succeed in a job out there only because you're Black. You live in the slum, you are less educated, and thus everything is more difficult. That is what poverty means", claims Elisete da Silva Napoleão, 39, one of the seamstresses in the group.). (Folha, 30/06/03)

In 20), below, perhaps the only occurrence of this new priming in beleza negra (black beauty) with a positive semantic prosody, the association is with carnavalescos (carnivalesque). However, I argue, carnival itself is a widespread, stereotypical representation of Brazil as a racially democratic country; also, if we understand carnival in Bakhtin's terms (see Bakthin, 1981), it could be seen as a representation of one of the rarest moments where power is suspended and Brazilians of African descent would be allowed to participate in a society with a huge social difference between people at the ends of a skin colour line:

20) Os blocos afro-carnavalescos cantavam a beleza negra. (Afro carnivalesque groups chanted black beauty.) (Folha, 01/02/03)

I would like to round up this section adding two examples from an essay published in the broadsheet to the analysis of discourse representation and interdiscursivity in the news reports. It is an essay on intolerance, written by Sergio Paulo Rouanet, a contemporary sociologist. The semantic 
relation between poverty and race as well as the conflicting uses of lexical items from race and skin colour classifications can also be traced in his essay, as shown in examples 21) and 22) below, the latter mapping the sociologist's basis for race classification onto (again) another, that of skin colour (notice his reference to differences of colour) and separate from class (notice his paradoxical listing of skin colour and social condition, or class as separate issues):

21) O problema, entre nós, é o estado de pobreza em que vive a maioria da população negra. Enquanto persistir essa situação, os negros serão vítimas de uma intolerância dupla, sobredeterminada, que os atinge enquanto negros e enquanto pobres. (The problem amongst us is the condition of poverty in which most Black population lives. As long as this situation goes on Blacks will be victims of a double, over determined intolerance which addresses them as Blacks and as poor.). (Folha, 09/02/03)

22) Os alunos aprenderiam a aceitar e compreender as diferenças_de cor, de gênero, de orientação sexual, de condição social. (Students would learn to accept and understand difference - difference in skin colour, gender, sexual orientation, and social condition.). (Folha, 09/02/03)

\section{Data analysis and discussion 3: dialogicality and difference}

I would like to reflect upon dialogicality and difference in the reports, following Fairclough's range of dialogicality and taking into account the different forms of attribution of dialogue in texts. Fairclough (2003: 41) presents five different scenarios concerning the nature of orientation to difference in texts:

(a) an openness to, acceptance of, recognition of difference; an exploration of difference, as in 'dialogue' in the richest sense of the term;

(b) an accentuation of difference, conflict, polemic, a struggle over meaning, norms, power;

(c) an attempt to resolve or overcome difference;

(d) a bracketing of difference, a focus on commonality, solidarity;

(e) consensus, a normalization and acceptance of differences of power which brackets or suppresses differences of meaning and norms

He draws attention to the fact that the scenarios are not meant as a typology of social events and interactions for they may be combined in various ways in texts and social events. An investigation of the way they 
are combined through the different representations of discourses in the news reports analysed is useful in the interpretation of the different lexical choices made and the semantic relations created to report race.

I would like to argue the scenarios could be best applied to a small scale analysis of texts, preferably of a report in relation to the text which originated it (not an easy task, to start with, in the case of mediated discourse). With a larger scale analysis such as the one developed here the best I can do is to recognize that the more different voices/discourses represented the more dialogical and open to difference the text/corpus will tend to be. The broadsheets, including the one analysed in this research, in general claim to be dialogical and to represent impartially as many voices as possible. Even though there are many legitimised academic studies that indicate the opposite, one can also attest that because of their mediated status they are inevitably and paradoxically both biased and dialogical.

A further step would be to recognize that the more appropriation there is of lexical choices/discourses in discourse representation the more tension, conflict and thus struggle over ideologies and power are at work which, I hope, I have shown in the analysis above. I suppose examples where a new lexical item (não-negras) challenges, even if not thoroughly, a monolithic classification, or examples where a word used in an unconventional way (e.g. negra in pobreza negra) contests race aestheticization by adding poorness to it, could be interpreted both as an accentuation of difference and as an attempt to overcome it. In addition, I suppose examples such as the one in which 'black beauty' is associated with carnival, i.e. when a stereotype is retrieved, the focus is one of solidarity and difference is bracketed or, I would rather say, suspended in the sense of the Bakthinian carnival.

Finally, to try an example of consensus, or rather of banalization of difference in the corpus, I would choose the one in which the girl's DS on her attempt at facing racial prejudice at school could be interpreted as assessed in the report as giving a recipe. The metaphoricization of her steps towards affirmative action as instructions in a recipe may blur the meaning of a new, symbolic action and, thus, discourse, transferring them to the realm of everyday, common sense activities long being taken in the society. 


\section{Final Remarks}

I would like to emphasize the investigation carried out adds to studies in the field by reinforcing concordance lines as a useful tool in analysing texts as social events. Furthermore, the analysis indicates racial democracy is still a strong discourse mediated through the broadsheet analysed as far as it is grounded on skin colour classification, on the one hand; on the other, it also suggests that this discourse is no longer hegemonic inasmuch as other, new discourses such as the one of affirmative action gradually come to the fore and struggle for power. This is done through unconventional choice of lexical items or creation of new semantic relations which push the skin colour classification onto a race/cultural classification which will perhaps address a stronger (re)construction of African heritage in Brazil and hopefully elsewhere.

The semantic relations as foregrounded by the first analysis have been displaced, or rather re-placed to the background of the discourses represented in the texts. The combination of the two tools, the analysis of semantic relations and the investigation of interdiscursivity, has allowed for the perception of tensions over terms of skin colour and race in the conflicting discourses mediated by the paper. In addition, it has allowed for a cautious interpretation of the range of dialogicality and thus of the different orientations to racial difference in the mediated language of the reports. The broadsheet analysed has indeed provided room albeit in different scales to different discourse representations in society, including of those who are racially and socially excluded and who talk back from this perspective. As a consequence of dialogicality, the discourse of racial democracy still strikes, or writes back or, I would rather say, haunts voices or discourses but it is no longer as stable as it had attempted to be for a long time. On the contrary, it may be beginning to be undermined in order to reveal the many years of social discrimination and exclusion of people of African descent in Brazil. The five scenarios of orientation to difference proposed by Fairclough (2003) could also be traced in the analysis, which I see as another indication of change in the wider discourse and hopefully in real affirmative action in the society. 


\title{
Acknowledgements
}

This research is funded by Conselho Nacional de Desenvolvimento da Pesquisa (CNPq), Brazil. The author gratefully acknowledges the comments from Norman Fairclough, Greg Myers and Adriana Pagano to the several versions of this paper.

\author{
Recebido em outubro de 2005 \\ Aprovado em abril de 2006 \\ E-mail: cmagalhaes@letras.ufmg.br
}

\section{REFERENCES}

Bakhtin, Mikhail. 1981. Particularidades do Gênero e TemáticoComposicionais das Obras de Dostoievsky. In: Problemas da Poética de Dostoievsky. Rio de Janeiro: Editora Forense-Universitária: 87-156.

. 1986. The problem of speech genres. In: The Problem of Speech Genres and Other Late Essays. Austin: University of Texas Press: 60-102.

Barbara, Leila \& Carlos Gouveia. 2001. It is not there, but (it) is cohesive: the case of pronominal ellipsis of subject in Portuguese. Direct Papers. 46 http://lael.pucsp.br/direct/DirectPapers46.pdf

Bell, Alan. 1991. The Language of News Media. Oxford, UK e Cambridge, MA: Blackwell.

Borba, Francisco. 2002. Dicionário de Usos do Português do Brasil. São Paulo: Ática.

Bourdieu, Pierre. 1984. Distinction: A Social Critique of the Judgement of Taste. Cambridge, MA: Harvard University Press.

ButTNY, Richard. 1997. Reported speech in talking race on campus. Human Communication Research. 23: 4, 1997. p. 477-506.

Buttny, Richard \& P. L. Williams. 2000. Demanding respect: the uses of reported speech in discursive constructions of interracial contact. Discourse E Society, 11:1: 109-133.

Caetano, Paulo \& Célia Magalhães. Forthcoming. Relações lexicais e construções da questão racial em jornais impressos brasileiros (PhD dissertation under supervision).

Carone, Iray. 2003. Breve histórico de uma pesquisa psicossocial sobre a questão racial brasileira. In Iray CARONe \& Maria Aparecida Bento. Orgs. Psicologia Social do Racismo: Estudos sobre branquitude e branqueamento no Brasil. Petrópolis: Editora Vozes: 13-23. 
Carone, Iray \& Isildinha B. Nogueira. 2003. Faíscas elétricas na imprensa brasileira: a questão racial em foco. In: Iray CARONE \& Maria Aparecida S. Bento. Orgs. Psicologia Social do Racismo: Estudos sobre Branquitude e Branqueamento no Brasil. Petrópolis: Editora Vozes: 163-180.

Chouliaraki, Lilie \& Norman Fairclough. 1999. Discourse in Late Modernity: Retbinking Critical Discourse Analysis. Edinburgh U.P.

D’ADESKY, Jacques. 2001. Pluralismo Étnico e Multiculturalismo: Racismos e Anti-racismos no Brasil. Rio de Janeiro: Pallas.

Fairclough, Norman. 1992. Discourse and Social Change. Oxford, UK; Cambridge, MA: Polity Press.

. 1995. Media Discourse. London e New York: Edward Arnold. . 1995. Discourse Representation in Media Discourse. In: Critical Discourse Analysis: the critical study of language. Essex: Longman Group: 54-69.

. 2001. The Discourse of New Labour: Critical Discourse Analysis. In: Margaret Wetherell, S. Taylor \& S. J. Yates. Eds. Discourse as data: A Guide for Analysis. London: Sage: 229-266.

. 2003. Analysing Discourse:Textual Analysis for Social Research. London; New York: Routledge.

Folha de São Paulo/Datafolha. Racismo cordial. 1995. A mais completa análise sobre preconceito de cor no Brasil. São Paulo: Atica.

Fowlen, Roger. 1991. Language in the news : discourse and ideology in the press. London; New York: Routledge.

Freyre, Gilberto. 1966. Casa Grande e Senzala. Rio de Janeiro: José Olympio. Guimarães, Antonio Sérgio. 2003. Racial insult in Brazil. Discourse E Society. 14:2: 133-151.

Hardt-Mautner, Gerlinde. 1995. 'Only connect.' Critical discourse analysis and corpus linguistics'. http://www.comp.lancs.ac.uk/computing/ research/ucrel/papers/techpaper/vol6.pdf

Hoey, Michael. 1991. Another Perspective on Coherence and Cohesive Harmony. In: Eija Ventola. Ed. Functional and Systemic Linguistics: Approaches and Uses. Berlin; New York: Mouton de Gruyter: 385-413. . Forthcoming. Lexical priming and the properties of text. In: A. Partington, J. Morley \& L. Hahrman. Eds. Corpora and Discourse. Bern: Peter Lang.

Holanda Ferreira, Aurélio de. 2004. Dicionário da Lingua Portuguesa. Edição eletrônica autorizada à POSITIVO INFORMÁTICA LTDA. 
Krishnamurthy, Ramesh. 1996. Ethnic, Racial and Tribal: The Language of Racism? In: C. R. Caldas-Coulthard \& Malcolm Coulthard. Eds. Texts and Practices: Readings in Critical Discourse Analysis. London; New York: Routledge: 129-149.

LeECH, Geoffrey \& Michael Short. 1981. Style in Fiction. London: Longman. Lemke, Jay. 1995. Textual Politics: Discourse and Social Dynamics. London and Bristol, PA: Taylor e Francis.

MaGAlHÃEs, Célia. Interdiscursividade e conflito entre discursos sobre raça em reportagens brasileiras. 2004. Linguagem em (Dis) Curso. 4/Especial: $35-60$.

Myers, Greg. 1999. Unspoken Speech: Hypothetical Reported Discourse and the Rhetoric of Everyday Talk. Text, 19: 4: 571-590.

Nascimento, Elisa; 2003. O Sortilégio da Cor: Identidade, Raça e Gênero no Brasil. São Paulo: Summus.

Partington, Alan. 1998. Patterns and Meanings: Using Corpora for English Language Research and Teaching. Amsterdam; Philadelphia: John Benjamins.

PizA, Edith. 2003. Porta de Vidro: Entrada para a Branquitude. In: Iray Carone \& Maria Aparecida Bento. Orgs. Psicologia Social do Racismo: Estudos sobre Branquitude e Branqueamento no Brasil. Petrópolis: Editora Vozes: 59-90.

Piza, Edith \& Fúlvia Rosemberg. 2003. Cor nos Censos Brasileiros. In: Iray Carone \& Maria Aparecida Bento. Orgs. Psicologia Social do Racismo: Estudos sobre Branquitude e Branqueamento no Brasil. Petrópolis: Editora Vozes: 91-120.

ReIsigl, Martin \& Ruth Wodak. 2001. 'Race', Racism and Discourse. In: Discourse and Discrimination: Rhetorics of Racism and Antisemitism. London and New York: Routledge: 1-30.

Sardinha, Tony Berber. 2004. Lingüística de Corpus. Barueri, SP: Manole. Schwarcz, Lília. 2000. Raça como negociação: sobre teorias raciais em finais dos século XIX no Brasil. In: Maria Nazareth Fonseca. Org. Brasil Afro-Brasileiro. Belo Horizonte: Autêntica: 11-40.

Scollon, Ron. 1998. Mediated Discourse as Social Interaction: a Study of News Discourse. London and New York: Longman.

Scotт, Michael. Focusing on the Text and its Key Words. In: Rethinking Language Pedagogy from a Corpus Perspective. Frankfurt am Main: Peter Lang: 103-121.

SinclaIr, John. 1991. Corpus, Concordance, Collocation. Oxford : OUP. 
Short, Michael, Elena Semino \& J. Culpeper. 1996. Using a corpus for stylistics research: speech and thought presentation. In: J. THOMAS and M. SHORT Using Corpora for Language Research. London and New York: Longman, 1996: 110-131.

Sodré, Muniz. 2000. Claros e Escuros: Identidade, Povo e Mídia no Brasil. Petrópolis, RJ: Vozes.

StubBs, Michael. 1996. Text and corpus analysis. Oxford: Blackwell Publishers. Thompson, Geoff. 1996. Voices in the Text: Discourse Perspectives on Language Reports. Applied Linguistics. 17: 4: 501-530.

VAn DIJK, Teun et al. 1998. Discourse, Ethnicity, Culture and Racism. In:

Teun van Dijk Ed. Discourse as Social Interaction. London, Thousand Oaks, New Delhi: Sage Publications: 140-180.

VAn Dijk, Teun. 1986. News Schemata. In: C. R. Cooper \& S. Greenbaum. Studying Writing: Linguistic Approaches. London: Sage: 151-185. . 2003. Dominación étnica y racismo discursivo en España y América Latina. Barcelona: Gedisa.

Van leeuwen, Theo. 1996. The Representation of Social Actors. In: C. R.

Caldas-Coulthard \& Malcolm Coulthard. Eds. Texts and Practices: Readings in Critical Discourse Analysis. London; New York: Routledge: 32-70.

Vološinov, V. N. 1978. Reported speech. In: L. Matejka \& K. Pomorska. Eds. Readings in Russian Poetics. Ann Harbor, Michigan; Michigan Slavic Publications: 149-175.

Williams, Raymond. 1988. Keywords: A Vocabulary of Culture and Society. London: Fontana Press.

Wodak, Ruth \& Michael Meyer. Eds. 2002. Methods of Critical Discourse Analysis. London, Thousand Oaks, New Delhi: Sage.

WODAK, Ruth. 2002. The Discourse-historical Approach. In: Ruth WODAK \& Michael Meyer. Eds. Methods of Critical Discourse Analysis. London, Thousand Oaks, New Delhi: Sage: 63-94. 